\title{
Dry brewery residue in broiler chickens feed
}

\section{Resíduo seco de cervejaria na alimentação de frangos de corte}

\author{
Wiliam Parpinelli ${ }^{1}$; Paulo Segatto Cella ${ }^{2}$; Vaneila Daniele Lenhardt Savaris ${ }^{3 *}$; \\ Jomara Broch ${ }^{3}$; Ricardo Vianna Nunes ${ }^{4}$
}

\begin{abstract}
The residual from the food industry has the potential to replace the traditional ingredients used in animal feed, and the dry brewery residue (DBR) may be an alternative for this purpose. This study aimed to evaluate the use of DBR in the diets of broiler from 22 to 42 days of age. Five hundred and forty-six male broilers were used, with an initial average weight of $865 \pm 8 \mathrm{~g}$. The animals were distributed in a completely randomized design, with six levels of DBR inclusion $(0,2,4,6,8,10 \%)$, seven replicates and thirteen animals per experimental unit (EU). Weight gain (WG), average feed intake (AFI) and feed:gain ratio were evaluated. At 42 days of age, blood samples were collected from two broilers of each EU, and one broiler per EU was slaughtered to investigate the intestinal development. DBR interposed the WG and promoted a linear effect in this variable from 22 to 42 days of age. This effect was not observed for AFI. The inclusion of DBR interfered with the serum cholesterol values, showing a quadratic influence at the maximum response for the inclusion of $4.96 \%$. However, the blood parameters of triglycerides, uric acid, creatinine, aspartate aminotransferase, alanine aminotransferase and total protein remained unchanged, regardless of the level of dietary DBR. No changes in villus height and crypt depth were observed by intestinal morphometric evaluation. The inclusion of $10 \%$ DBR can be used in a poultry diet, without any damage to the performance, metabolism and development of the broilers.
\end{abstract}

Key words: Alternative feed. Brewery industry. Co-product. Performance.

\section{Resumo}

Os resíduos da indústria alimentícia tem potencial para substituição dos ingredientes tradicionalmente utilizados nas rações animais, neste contexto o resíduo seco de cervejaria (RSC) pode ser uma alternativa para esta finalidade. Este estudo teve o objetivo de avaliar o RSC em rações de frangos de corte dos 22 a 42 dias de idade. Foram utilizados 546 pintos, machos, com peso médio inicial de $865 \pm 8 \mathrm{~g}$, distribuídos em um DIC, com 6 níveis de inclusão de RSC $(0 ; 2 ; 4 ; 6 ; 8 ; 10 \%), 7$ repetições e 13 animais por unidade experimental (UE). Foi realizada avaliação do ganho de peso (GP), consumo médio de ração (CMR) e conversão alimentar (CA). Aos 42 dias foram coletadas amostras de sangue de duas aves por UE, e abatida uma ave por UE, para avaliar o desenvolvimento das vilosidades intestinais. O RSC interferiu no GP promovendo um efeito linear sobre esta variável dos 22 aos 42 dias de idade, efeito este não observado para a CA e o CMR. A inclusão de RSC interferiu nos valores séricos de colesterol, com um efeito quadrático ao ponto máximo de resposta no nível de $4,96 \%$ de inclusão. No entanto, os

1 M.e em Zootecnia, Programa de Pós-Graduação em Zootecnia, PPGZO, Universidade Tecnológica Federal do Paraná, UTFPR, Dois Vizinhos, PR, Brasil. E-mail: william.parpinelli@yahoo.com

2 Prof. Dr., Curso de Graduação em Zootecnia, UTFPR, Dois Vizinhos, PR, Brasil. E-mail: pscella@hotmail.com

3 Discentes, Curso de Doutorado, Programa de Pós-Graduação em Zootecnia, Universidade Estadual do Oeste do Paraná, UNIOESTE, Marechal Cândido Rondon, PR, Brasil. E-mail: vaneilalenha@hotmail.com; brochjomara@yahoo.com.br

4 Prof. Dr., Programa de Pós-Graduação Stricto Sensu em Zootecnia, UNIOESTE, Marechal Cândido Rondon, PR, Brasil. E-mail: nunesrv@hotmail.com

* Author for correspondence 
parâmetros sanguíneos de triglicerídeos, ácido úrico, creatinina, aspartato aminotransferase, alanina aminotrasferase e proteína total permaneceram inalterados independente do nível de RSC da dieta. Não foram observadas alterações nas vilosidades e profundidade de criptas pela avaliação morfometrica intestinal. A inclusão de $10 \%$ de RSC pode ser realizada sem que ocorram danos ao desempenho, metabolismo e desenvolvimento das aves.

Palavras-chave: Alimento alternativo. Co-produto. Desempenho. Indústria cervejeira.

\section{Introduction}

The demand for animal protein by the population places constant pressure on the meat production sectors, such as the poultry sector. However, this increase in the production of broilers results in an increased need for raw materials to feed the animals. This requirement has driven the research for new food sources that replace or can be used as effective ingredients within the nutritional programs. In this context, the by-products of the food industries become the main alternatives and sources for this purpose.

The use of by-products in animal diets can reduce the incorrect disposal of these products into the environment. Also, their use as an alternative source in animal feed may replace or complement other ingredients of high added-value, which are used as food sources in human diets. When used in broiler diets, these alternative ingredients can reduce production costs, resulting in more economically viable and nutritionally productive feed.

The brewing sector is one of the most important in the Brazilian economy, accounting for $1.6 \%$ of the national gross domestic product, with approximately 14.1 billion liters produced annually (ASSOCIAÇÃO BRASILEIRA DA INDÚSTRIA DA CERVEJA - CERVBRASIL, 2017). Among the residues of this industry, the brewery residue, which is obtained during the brewing process, is substantial, with $20 \mathrm{~kg}$ of wet residue produced for every $100 \mathrm{~L}$ of beer (DENSTADLI et al., 2010).

Besides the wet brewery residue, the dry brewery residue (DBR) and brewer's yeast are also generated from this process. In Brazil, this residue is predominantly in the humid form (BROCHIER; CARVALHO, 2009). According to Denstadli et al. (2010), the storage stability of wet brewery residue represents a challenge, due to its low dry matter (DM) content and high microbial activity, which results in rapid deterioration when it is not conserved in the form of silage, or dried for storage. The main limitation related to the use of DBR in poultry feed is its high fiber content (about $130 \mathrm{~g}$ $\mathrm{kg}^{-1}$ of feed), which results in reduced digestibility by poultry (LEVIC et al., 2010).

The fibers present in foods are non-digestible in the small intestine and, consequently, fermented in the large intestine. Thus, the metabolism of some nutrients is affected by the gastrointestinal tract conditions, due to the physicochemical properties presented by the fibers (MIRA et al., 2009).

The DBR is a source of water-soluble proteins and vitamins (ODUNUKAN et al., 2016). In addition, it can be inferred that the brewery residue has other components, such as yeast and yeast cell walls, ingredients that when included in diets of broiler chickens, can improve the performance and intestinal morphology of these animals (LI et al., 2016). Thus, the inclusion of DBR in broiler diets may result in the reduction of industrial amino acid supplementation in feed, thereby reducing production costs and lowering excessive nitrogen excretion.

Thus the current research evaluated the use of DBR as an ingredient in the diets of broilers during 22 to 42 days of life, to measure the possible effects of this inclusion on the development of the birds.

\section{Material and Methods}

This work was performed in the experimental aviary of the Federal University of Technology, 
Paraná, Dois Vizinhos Campus. All procedures were approved by the UTFPR Ethics and Animal Research Committee (protocol 2014-005). The experiments were undertaken over 21 days, during the growth phase of the birds. A total of 546 male Cobb 500 broilers, with an initial age of 21 days and an initial weight of $865 \pm 8 \mathrm{~g}$, were studied. From 1 to 21 days of age, the birds were fed a single initial feed, formulated according to the nutritional requirements recommended by Rostagno et al. (2011). Throughout the experimental period, the birds were kept within the zone of thermal comfort, using a negative ventilation system.

The experimental design was completely randomized, consisting of 6 different inclusion levels of the $\operatorname{DBR}(0,2,4,6,8$ and $10 \%)$, with 7 replicates and 13 birds per experimental unit (EU). Feeding was done using individual tubular feeders by EU, and water by nipple type feeders. Both feed and water were supplied ad libitum. The experimental feeds (Table 1) were formulated with corn and soybean meal, and their nutritional requirements concurred with those recommended by Rostagno et al. (2011).

Table 1. Percentage and calculated composition of the experimental feeds for broiler chickens from 22 to 42 days of age, receiving dry brewery residue (DBR).

\begin{tabular}{lcccccc}
\hline \multirow{2}{*}{ Ingredient } & \multicolumn{7}{c}{ DBR inclusion (\%) } \\
\cline { 2 - 7 } & 0 & 2 & 4 & 6 & 8 & 10 \\
\hline Corn grain & 62.82 & 60.69 & 58.55 & 56.42 & 54.29 & 52.35 \\
Soybean meal (46\%) & 31.01 & 30.53 & 30.04 & 29.55 & 29.07 & 28.40 \\
Soybean oil & 2.52 & 3.14 & 3.77 & 4.39 & 5.02 & 5.60 \\
Dicalcium phosphate & 1.273 & 1.264 & 1.256 & 1.247 & 1.238 & 1.230 \\
Limestone & 0.936 & 0.936 & 0.936 & 0.936 & 0.935 & 0.936 \\
Sodium chloride & 0.442 & 0.444 & 0.446 & 0.448 & 0.450 & 0.455 \\
Lysine sulfate (51.7\%) & 0.407 & 0.412 & 0.416 & 0.420 & 0.425 & 0.451 \\
DL-Methionine (99\%) & 0.277 & 0.275 & 0.272 & 0.270 & 0.268 & 0.267 \\
L-Threonine (98\%) & 0.084 & 0.083 & 0.083 & 0.083 & 0.082 & 0.084 \\
Supplement minerals and vitamins ${ }^{1}$ & 0.150 & 0.150 & 0.150 & 0.150 & 0.150 & 0.150 \\
Salinomycin 12\% & 0.050 & 0.050 & 0.050 & 0.050 & 0.050 & 0.050 \\
BHT & 0.020 & 0.020 & 0.020 & 0.020 & 0.020 & 0.020 \\
Enramycin 5\% & 0.010 & 0.010 & 0.010 & 0.010 & 0.010 & 0.010 \\
Dry brewery residue & 0.000 & 2.000 & 4.000 & 6.000 & 8.000 & 10.000 \\
\hline Total & 100.00 & 100.00 & 100.00 & 100.00 & 100.00 & 100.00 \\
\hline Metabolizable energy (kcal kg-1) & 3100 & 3100 & 3100 & 3100 & 3100 & 3100 \\
Crude protein (\%) & 19.90 & 19.90 & 19.90 & 19.90 & 19.90 & 19.90 \\
NDF (\%) & 11.77 & 12.75 & 13.73 & 14.71 & 15.69 & 16.66 \\
ADF (\%) & 4.63 & 5.02 & 5.42 & 5.82 & 6.21 & 6.60 \\
Calcium (\%) & 0.758 & 0.758 & 0.758 & 0.758 & 0.758 & 0.758 \\
Available phosphorus (\%) & 0.354 & 0.354 & 0.354 & 0.354 & 0.354 & 0.354 \\
Digestible lysine (\%) & 1.131 & 1.131 & 1.131 & 1.131 & 1.131 & 1.131 \\
Digestible methionine (\%) & 0.539 & 0.538 & 0.537 & 0.537 & 0.536 & 0.536 \\
Digestible methionine + cystine (\%) & 0.826 & 0.826 & 0.826 & 0.826 & 0.826 & 0.826
\end{tabular}


continuation

\begin{tabular}{lllllll} 
Digestible threonine (\%) & 0.735 & 0.735 & 0.735 & 0.735 & 0.735 & 0.735 \\
Potassium (\%) & 0.756 & 0.741 & 0.725 & 0.710 & 0.695 & 0.677 \\
Sodium (\%) & 0.200 & 0.200 & 0.200 & 0.200 & 0.200 & 0.200 \\
\hline
\end{tabular}

${ }^{1}$ Vitamin A $10 \mathrm{IU}$, vitamin $\mathrm{D}_{3} 2.500 \mathrm{IU}$, vitamin E $20 \mathrm{IU}$, vitamin $\mathrm{K}_{3} 2.5 \mathrm{mg}$, vitamin $\mathrm{B}_{1} 1.8 \mathrm{mg}$, vitamin $\mathrm{B}_{2} 6000 \mathrm{mg}$, vitamin $\mathrm{B}_{12}$ $16 \mathrm{mcg}$, vitamin $\mathrm{B}_{6} 2.6 \mathrm{mg}$, nicotinic acid $40 \mathrm{mg}$, pantothenic acid $12 \mathrm{mg}$, biotin $65 \mathrm{mg}$, folic acid $1 \mathrm{mg}$, iron $50 \mathrm{mg}$, copper $9 \mathrm{mg}$, zinc $60 \mathrm{mg}$, manganese $70 \mathrm{mg}$, iodine $1 \mathrm{mg}$, selenium $300 \mathrm{mg}$, vehicle qsp $1.000 \mathrm{~g}$.

The DBR used in the experimental rations presented as a bromatological composition in the natural matter, $91.58 \% \mathrm{DM}, 29.53 \%$ crude protein (CP), $4527 \mathrm{kcal} \mathrm{kg}^{-1}$ crude energy, $4.96 \%$ fat, $65.00 \%$ neutral detergent fiber (NDF), $25.40 \%$ acid detergent fiber (ADF) and $1924 \mathrm{kcal} \mathrm{kg}^{-1}$ corrected apparent metabolizable energy for nitrogen balance (AMEn).

The zootechnical variables evaluated during the experimental period were weight gain (WG), mean feed intake (MFI) and feed conversion (FC), from 22 to 42 days of age. The FC values were calculated according to feed consumption and $\mathrm{WG}$ for the period. When necessary, these values were corrected for mortality, according to the method proposed by Sakomura and Rostagno (2016).

At 42 days of age, blood was collected by ulnar vein puncture of two birds per EU after a 6-h fast, for evaluation of blood metabolites. The blood samples were centrifuged and the serum stored at $-20^{\circ} \mathrm{C}$, for subsequent analyzes.

The blood was evaluated for cholesterol (COL), triglycerides (TAG), uric acid (UA), creatinine (CRE), aspartate aminotransferase (AST), alanine aminotransferase (ALT), albumin (ALB), urea (UR) and total protein (TP), using commercial kits (Elitech SA) and a biochemical autoanalyzer (Flexor EL-200, Elitech), with automatic calibration.

At 42 days of age, one bird per EU was selected, varying $\pm 5 \%$ of the EU average weight. These birds were slaughtered by cervical dislocation. Then, the duodenal segment $(4 \mathrm{~cm})$ was collected, to identify problems in the cellular development of the intestine that could be caused by including the DBR in the diet. After collection, the intestinal fragments were fixed on a rigid surface and submerged in $10 \%$ formalin for $24 \mathrm{~h}$, followed by storage in $70 \%$ alcohol solution, for further processing.

Histological sections were prepared by increasing dehydration in alcohol, diaphanization in xylol and inclusion in histological paraffin. Thin sections (5 $\mu \mathrm{m}$ thick) of the biological samples were obtained by using a microtome, then fixed on slides and stained with hematoxylin and eosin (BEÇAK; PAULETE, 1976). For the measurement of the villi height and crypt depth, the slides were digitalized using a light-equipped photomicroscope, coupled to a computer with image analysis software (ImageTool 3.0), developed by the University of Texas. In total, 20 villi were measured for their extensions, and 20 crypts for their depth.

The length of each intestinal villus was defined as the distance between the upper extremity of the villi and the lower portion of the villi bounded by the presence of intestinal glands. For crypt depth, the depth of the crypts of Lieberkühn, located between two villi, was measured, which extends through the proper lamina to the muscle tissue.

The data obtained from the evaluated variables of performance, blood parameters and intestinal morphometry were analyzed using the Statistical Analysis System, SAEG, developed by the Federal University of Viçosa (UNIVERSIDADE FEDERAL DE VIÇOSA, 1999). The best levels of DBR inclusion were established using polynomial regression models. 


\section{Results and Discussion}

According to the results obtained for performance from 22 to 42 days of age (Table 2), an increasing linear effect $(p<0.05)$ was observed only for the WG, which improved with the inclusion of the evaluated residue.

The inclusion of DBR improved the WG of the birds, probably by providing a better nutritional contribution in the diets with higher inclusion of DBR. This nutritional contribution may be linked to a better digestibility of the nutrients present in this food. The dietary intake did not have a significant effect, demonstrating the nutritional balance of the diets, even when using increasing levels of DBR. Consequently, the use of DBR provided better WG, with similar FC, among all treatments studied (Table 2).

Table 2. Performance of broilers in the 22 to 42 -day-old phase fed with increasing levels of dry brewery residue (DBR).

\begin{tabular}{lccc}
\hline \multirow{2}{*}{ DBR inclusion (\%) } & MFI $(\mathrm{kg})$ & WG $(\mathrm{kg})$ & FC $\left(\mathrm{kg} \mathrm{kg}^{-1}\right)$ \\
\cline { 2 - 4 } & & 22 to 42 days of age \\
\hline 0 & 3.355 & 1.937 & 1.732 \\
2 & 3.352 & 1.908 & 1.757 \\
4 & 3.394 & 1.935 & 1.754 \\
6 & 3.407 & 1.958 & 1.740 \\
8 & 3.416 & 2.004 & 1.704 \\
10 & 3.390 & 1.956 & 1.733 \\
\hline CV (\%) & 1.98 & 2.52 & 2.22 \\
\hline SEM & 0.0104 & 0.0085 & 0.0061 \\
\hline p & 0.374 & 0.026 & 0.153 \\
Linear & & 0.014 & \\
\hline
\end{tabular}

MFI: mean feed intake; WG: weight gain; FC: feed conversion; CV: coefficient of variation; SEM: standard error of the mean; p: probability.

The values found for FC are in agreement with those found by Silva (2013), who, in a study evaluating the productive potential of the Cobb lineage, observed $1,710 \mathrm{~kg}$ of feed per $\mathrm{kg}$ of chicken, for birds at 42 days of age. This result indicates that the inclusion of DBR, which despite having a high fiber content (NDF and ADF), did not represent a limiting role for the development of the birds, having little interference with the nutritional value of the diet.

Levic et al. (2010), investigating the use of brewery by-products in breeding birds, verified that these residues did not affect the performance of the birds. The finding was explained by the protein composition, which, when supplemented with industrial lysine, tended to be similar to the protein present in the bran of soybean. Also, these by-products had a higher energy density compared to soybean meal. The performance results can be confirmed by evaluating the morphology of the intestinal villi (Table 3), where the inclusion of DBR did not affect $(\mathrm{p}<0.05)$ the villi length and duodenal crypt depth of the birds. 
Table 3. Morphology of villi, crypt depth and villus:crypt (V/C) relationship of the duodenum of broilers slaughtered at 42 days of age and fed with increasing levels of dry brewery residue (DBR).

\begin{tabular}{cccc}
\hline DBR inclusion $(\%)$ & Villi $(\mu \mathrm{m})$ & Crypt $(\mu \mathrm{m})$ & V/C relationship \\
\hline 0 & 1259.8 & 208.1 & 6.05 \\
2 & 1260.6 & 207.0 & 6.08 \\
4 & 1265.4 & 207.3 & 6.10 \\
6 & 1255.3 & 209.1 & 6.01 \\
8 & 1251.8 & 211.9 & 5.91 \\
10 & 1255.5 & 208.0 & 6.04 \\
\hline CV & 1.54 & 3.42 & 3.68 \\
\hline SEM & 2.883 & 1.063 & 0.033 \\
\hline p & 0.818 & 0.780 & 0.658 \\
\hline
\end{tabular}

CV: coefficient of variation; SEM: standard error of mean; p: probability.

The morphophysiological results for all DBR inclusion levels were similar to each other. Although no significant changes were observed in villi length and crypt depth, the formation of bifurcations in the intestinal material analyzed was verified. Such a finding could explain the lack of adverse impacts on the performance of the birds, considering that the development of this type of alteration occurs as a way for the organism to compensate for the difficulty of absorption, by increasing the contact surface (ALEIXO et al., 2011). In a study assessing the inclusion of brewer's yeast wall, broiler diets resulted in increased villi height and jejunum crypt depth, relative to diets containing nucleotides and distillers dried grains with solubles (DDGS), in birds at 21 days of age. This increase in villi height resulted in increased digestion and absorption of nutrients. Likewise, the greater crypt depth is related to the higher turnover of the tissues that occurred as a result of the normal cellular losses caused in the tissue (ALIZADEH et al., 2016).

The crypt depth values were dissimilar to those reported for animals fed with basal diets containing $18.8 \%$ CP (FAVERI et al., 2015). Nonetheless, the crypt depth values did not present a negative effect, due to the high levels of fiber present in the diet. This type of response, however, is unusual because when foods with high fiber contents are consumed, they can cause lesions on the intestinal surface, with consequent local tissue thickening and increased crypt depth (DOWLING, 1992).

The lack of intestinal villi impairment and crypt depth evidenced the best performance of the birds. Namely, considering there was no negative or positive effect of the fiber on the development of the intestine of the birds, probably the use of DBR did not interfere with the digestion and absorption of the nutrients, providing better WG for the birds.

Denstadli et al. (2010) observed that the inclusion of up to $20 \%$ DBR in the diet of ROSS 360 broilers during 12 to 33 days of age did not affect the WG and FC of the birds when compared with the control treatment. However, these researchers did not perform nutritional adjustments of the diets evaluated. That is, with the increases in the inclusion of DBR, there was a decrease in energy levels and a nutritional imbalance of the studied diets. Possibly, the presence of yeasts in the composition of DBR may have caused interferences in the results obtained in that study, since the rations with high inclusions of this ingredient showed an improvement in the performance of the birds. In addition, according to Odunukan et al. (2016), the heating of the grains used during the drying process of the wet brewery 
residue contributes to increase the palatability and raise the protein levels of this residue, being this protein commonly of high digestibility.

Another factor corroborating the functionality of DBR as a food source for broiler chickens is that the weight ( $885 \mathrm{~g})$ at the beginning of the experimental period was lower than that recommended for the lineage (Cobb 500) and age of the birds (COBBVANTRESS, 2009). Despite this, the birds obtained a compensatory WG that allowed achieving a value at the end of the experimental period within the range recommended as an ideal for slaughtering the lineage used, at 42 days of age.

The occurrence of compensatory WG during the use of DBR suggests that the fibrous portion of this residue, even at high concentrations did not interfere in the development of the birds. Such a result is possibly allied to the presence of yeasts that interacted beneficially in the development of the birds.

The values obtained with the use of DBR, compared to previous studies performed with other by-products, such as sunflower meal (FURLAN et al., 2001), DDGS (SCHONE et al., 2017) and cottonseed meal (CARVALHO et al., 2010), suggest that the brewery residue presents an underexplored nutritional capacity, with great potential for use in commercial poultry rations, provided it is dry.

The serum COL concentration in the birds at 42 days of age presented a quadratic effect $(\mathrm{p}<0.05)$. Conversely, the other variables evaluated, such as CRE, ALB, ALT, TAG, UA, AST, ALB, TP and UR, were not affected by the different inclusions of DBR (Table 4).

Table 4. Blood parameters of broilers at 42 days of age fed dry brewery residue (DBR) from 22 to 42 days of age.

\begin{tabular}{cccccccccc}
\hline $\begin{array}{c}\text { DBR inclusion } \\
(\%)\end{array}$ & $\begin{array}{c}\mathrm{COL} \\
\mathrm{mg} \mathrm{dL}^{-1}\end{array}$ & $\begin{array}{c}\mathrm{TAG} \\
\mathrm{mg} \mathrm{dL}^{-1}\end{array}$ & $\begin{array}{c}\mathrm{UA} \\
\mathrm{mg} \mathrm{dL}^{-1}\end{array}$ & $\begin{array}{c}\mathrm{CRE} \\
\mathrm{mg} \mathrm{dL}^{-1}\end{array}$ & $\begin{array}{c}\mathrm{AST} \\
\mathrm{IU} \mathrm{L}^{-1}\end{array}$ & $\begin{array}{c}\mathrm{ALB} \\
\mathrm{g} \mathrm{dL}^{-1}\end{array}$ & $\begin{array}{c}\mathrm{TP} \\
\mathrm{g} \mathrm{dL}^{-1}\end{array}$ & $\begin{array}{c}\text { ALT } \\
\mathrm{IU} \mathrm{L}^{-1}\end{array}$ & $\begin{array}{c}\text { UR } \\
\mathrm{m} \mathrm{dL}^{-1}\end{array}$ \\
\hline 0 & 130.4 & 33.5 & 2.53 & 0.18 & 423.8 & 1.50 & 3.31 & 11.1 & 1.90 \\
2 & 129.3 & 31.7 & 2.12 & 0.19 & 364.7 & 1.52 & 3.20 & 9.2 & 1.40 \\
4 & 141.2 & 33.7 & 2.15 & 0.19 & 410.1 & 1.59 & 3.23 & 9.7 & 1.90 \\
6 & 147.3 & 28.5 & 2.47 & 0.20 & 387.6 & 1.61 & 3.22 & 8.8 & 1.90 \\
8 & 134.4 & 28.3 & 2.03 & 0.20 & 351.2 & 1.63 & 3.39 & 7.7 & 1.40 \\
10 & 125.5 & 30.0 & 2.01 & 0.20 & 401.5 & 1.53 & 3.16 & 8.9 & 1.60 \\
\hline $\mathrm{CV}$ & 10.59 & 16.76 & 38.26 & 10.60 & 22.24 & 8.43 & 9.82 & 28.78 & 45.66 \\
\hline SEM & 2.403 & 0.837 & 0.129 & 0.003 & 13.388 & 0.020 & 0.048 & 0.423 & 0.118 \\
\hline $\mathrm{p}$ & 0.012 & 0.077 & 0.624 & 0.396 & 0.416 & 0.161 & 0.625 & 0.128 & 0.402 \\
Linear & 0.793 & & & & & & & & \\
Quadratic & 0.002 & & & & & & & & \\
\hline
\end{tabular}

\begin{tabular}{cc}
\hline $\mathrm{COL}=126.679+(6.12536 \times \mathrm{DBR})-\left(0.616964 \times \mathrm{DBR}^{2}\right)\left(R^{2}=0.59\right)$ \\
\hline $\mathrm{COL}$
\end{tabular}

COL: cholesterol; TAG: triglycerides; UA: uric acid; CRE: creatinine; AST: aspartate aminotransferase; ALB: albumin; TP: total protein; ALT: alanine aminotransferase; UR: urea; IU: international units; CV: coefficient of variation; SEM: standard error of mean; p: probability.

The TAG values of all the inclusions remained unchanged relative to the control diet. However, these results are well below those reported by Wang et al. (2014), who found $102 \mathrm{mg} \mathrm{dL}^{-1}$ of serum TAG.
However, they were similar to that found by Café et al. (2012) of $32.23 \mathrm{mg} \mathrm{dL}^{-1} \mathrm{TAG}$ in the blood serum of broiler chickens at 42 days of age, created in a thermoneutral environment. 
The UA levels were not influenced by the use of DBR. The amounts found were below those of Wang et al. (2014), who observed $8.0 \mathrm{mg} \mathrm{dL}^{-1}$ UA in the blood of DDGS fed broilers, and also, less those found by Donsbough et al. (2010), who obtained serum UA values of 6.58 and $6.39 \mathrm{mg} \mathrm{dL}^{-1}$ in chickens fed with diets deficient and adequate in amino acids, respectively. The levels found may indicate that the protein fraction of DBR was not able to enhance the accumulation of this metabolite in the body of the birds. Thus, the homeostasis of the amino acids was guaranteed independent of the protein source used and, consequently, there was no energy expenditure to catabolize the excess nitrogen. Similarly to the UA, the UR plasma values presented no variation, and were within the range proposed by Schmidt et al. (2007), of 0-5 $\mathrm{mg} \mathrm{dL}^{-1}$ of blood.

The CRE values presented a behavior comparable to that proposed by Saukas et al. (1994), who defined values between 0.16 and $0.41 \mathrm{mg} \mathrm{dL}^{-1}$ as the standard for this variable. Besides, the CRE contents detected in the current research were also similar to that obtained by Café et al. (2012), of $0.44 \mathrm{mg} \mathrm{dL}$ 1. The existence of alterations in the values of this variable is typically associated with pathological conditions, and its elevation is possibly indicative of a reduction of renal activity accompanied by a degeneration of the muscular tissue. Such changes could have been propitiated in response to high inclusions of this by-product, although this was not observed in this study.

The ALB level found in the current work is comparable with that obtained by Café et al. (2012), standing at $1.5 \mathrm{~g} \mathrm{dL}^{-1}$. The TP values are also close to those found by Café et al. (2012), which for broilers is $2.65 \mathrm{mg} \mathrm{dL}^{-1} \mathrm{TP}$ in the blood, and Wang et al. (2014), who obtained a TP of $2.71 \mathrm{mg} \mathrm{dL}^{-1}$ blood.

The COL values, although presenting close to those found by Wang et al. (2014), of $123.4 \mathrm{mg} \mathrm{dL}^{-1}$ for broiler chickens, showed a quadratic behavior, with a maximum point determined at $4.96 \%$ of DBR inclusion. Li et al. (2016) observed an increase in serum levels of total broiler chicks at 42 days of age that received diets containing yeast cell walls compared to diets free of this ingredient.

Increased concentrations of COL are often uncommon, especially with the use of a high fiber (NDF and ADF) residue, which is largely composed of non-starch polysaccharides. Among these polysaccharides, beta-glucans (BEDFORD, 1996) can reduce the plasma COL level, when present in high concentrations in the diets.

According to Mira et al. (2009), soluble fibers, such as beta-glucans, tend to delay gastric emptying and, consequently, glucose absorption. As a result, both the postprandial blood glucose and serum COL are reduced, because the physical characteristic of beta-glucan causes an increase in the luminal viscosity.

\section{Conclusion}

The inclusion of DBR up to $10 \%$ is recommended in diets for broilers during 22 to 42 days of age, without prejudice to the performance, blood parameters and intestinal morphology of the birds.

\section{References}

ALEIXO, V. M.; PRESSINOTI, L. N.; CAMPOS, D. V. S.; MENEZES-ALEIXO, R. C.; FERRAZ, R. H. S. Histologia, histoquímica e histometria do intestino de jacaré-do-Pantanal criado em cativeiro. Pesquisa Veterinária Brasileira, Seropédica, v. 31, n. 12, p. 11201128, 2011.

ALIZADEH, M.; RODRIGUEZ-LECOMPTE, J. C.; ROGIEWICZ, A.; PATTERSON, R.; SLOMINSKI, B. A. Effect of yeast-derived products and distillers dried grains with solubles (DDGS) on growth performance, gut morphology, and gene expression of pattern recognition receptors and cytokines in broiler chickens. Poultry Science, Champaign, v. 95, n. 3, p. 507-517, 2016.

ASSOCIAÇÃO BRASILEIRA DA INDÚSTRIA DA CERVEJA - CERVBRASIL. Dados do setor. São Paulo, 2017. Disponível em: <http://cervbrasil.org.br/paginas/ index.php?page=home $>$. Acesso em: 22 dez. 2017. 
BEÇAK, W.; PAULETE, J. Técnicas de citologia $e$ histologia. Rio de Janeiro: Livros Técnicos e Científicos Editora S. A., 1976. 230 p.

BEDFORD, M. R. Efeito del uso de enzimas digestivas en la alimentación de aves. Avicultura Profesional, Georgia, v. 14, n. 4, p. 24-29, 1996.

BROCHIER, M. A.; CARVALHO, S. Aspectos ambientais, produtivos e econômicos do aproveitamento de resíduo úmido de cervejaria na alimentação de cordeiros em sistema de confinamento. Ciência e Agrotecnologia, Lavras, v. 33, n. 5, p. 1392-1399, 2009.

CAFÉ, M. B.; RINALDI, F. P.; MORAIS, H. R.; NASCIMENTO, R.B.M.; MUNDIM,A.V.; MARCHINI, C. F. P. Biochemical blood parameters of broilers at different ages under thermoneutral environment. World's Poultry Science Journal, Salvador, p. 143-146, 2012. Supplement 1.

CARVALHO, C. B. de; DUTRA JÚNIOR, W. M.; REBELLO, C. B. V.; LIMA, S. B. P. de; TAKATA, F. N.; NASCIMENTO, G. R. do. Avaliação nutricional do farelo de algodão de alta energia no desempenho produtivo e características de carcaças de frangos de corte. Ciência Rural, Santa Maria, v. 40, n. 5, p. 1166-1172, 2010.

COBB-VANTRESS. Suplemento de crescimento e nutrição para frangos de corte. Arkansas: Cobb-Vantress, Inc., 2009. 8 p.

DENSTADLI, V.; BALLANCE, S.; KNUSTSEN, S. H.; WESTERENG, B.; SVIHUS, B. Influence of graded levels of brewers dried grains on pellet quality and performance in broiler chickens. Poultry Science, Champaign, v. 89, n. 12, p. 2640-2645, 2010.

DONSBOUGH, A. L.; POWELL, S.; WAGUESPACK, A.; BIDNER, T. D.; SOUTHERN, L. L. Uric acid, urea, and ammonia concentrations in serum and uric acid concentration in excreta as indicators of amino acid utilization in diets for broilers. Poultry Science, Champaign, v. 89, n. 2, p. 287-294, 2010.

DOWLING, R. H. Cellular and molecular basis of intestinal and pancreatic adaptation. Scandinavian Journal of Gastroenterology, Londres, v. 27, p. 64-67, 1992. Supplement 193.

FAVERI, J. C.; MURAKAMI, A. E.; POTENÇA, A.; EYNG, C.; MARQUES, A. F. Q.; SANTOS, T. C. dos. Desempenho e morfologia intestinal de frangos de corte na fase de crescimento, com e sem adição de nucleotídeos na dieta, em diferentes níveis proteicos. Pesquisa Veterinária Brasileira, Seropédica, v. 35, n. 3, p. 291-296, 2015.

FURLAN, A. C.; MANTOVANI, C.; MURAKAMI, A. E.; MOREIRA, I.; SCAPINELLO, C.; MARTINS, E. N.
Utilização do farelo de girassol na alimentação de frangos de corte. Revista Brasileira de Zootecnia, Viçosa, MG, v. 30, n. 1, p. 158-164, 2001.

LEVIC, J.; DJURAGIC, O.; SREDANOVIC, S. Use of new feed from brewery by-products for breeding layers. Romanian Biotechnological Letters, Bucharest, v. 15, n. 5, p. 5559-5565, 2010.

LI, X. H.; CHEN, Y. P.; CHENG, Y. F.; YANG, W. L.; WEN, C.; ZHOU, Y. M. Effect of yeast cell wall powder with different particle sizes on the growth performance, serum metabolites, immunity and oxidative status of broilers. Animal Feed Science and Technology, Amsterdam, v. 212, p. 81-89, 2016.

MIRA, G. S.; GRAF, H.; CÂNDIDO, L. M. B. Visão retrospectiva em fibras alimentares com ênfase em betaglucanas no tratamento do diabetes. Brazilian Journal of Pharmaceutical Sciences, São Paulo, v. 45, n. 1, p. 11-20, 2009.

ODUNUKAN, R. O.; AKINYEMI, D. O.; TANIMOLA, O. A.; BANKOLE, Y. O. Design, construction and performance analysis of brewery waste dryer. Asian Journal of Basic and Applied Sciences, Dubai, v. 3, n. 2, p. 27-42, 2016.

ROSTAGNO, H. S.; ALBINO, L. F. T.; DONZELE, J. L.; GOMES, P. C.; OLIVEIRA, R. F. de; LOPES, D. C.; FERREIRA, A. S.; BARRETO, S. L. T.; EUCLIDES, R. F. Tabelas brasileiras para aves e suínos: composição de alimentos e exigências nutricionais. 3. ed. Viçosa, MG: Universidade Federal de Viçosa, 2011. 252 p.

SAKOMURA, N. K.; ROSTAGNO, H. S. Métodos de pesquisa em nutrição de monogástricos. Jaboticabal: FUNEP - Fundação de Apoio a Pesquisa, Ensino e Extensão, 2016. 262 p.

SAUKAS, T. N.; KOHAYAGAWA, A.; BONFIM, S. R. M.; BORETTI, L. P. Parâmetros hematológicos em frangos de corte comercial. In: CONGRESSO BRASILEIRO DE MEDICINA VETERINÁRIA, 23., 1994, Olinda. Anais... Olinda: Associação Brasileira de Medicina Veterinária, 1994. p. 66-67.

SCHMIDT, E. M. S.; LOCATELLI-DITTRICH, R.; SANTIN, E.; PAULILLO, A. C. Patologia clínica em aves de produção - uma ferramenta para monitorar a sanidade avícola - revisão. Archives of Veterinary Science, Curitiba, v. 12, n. 3, p. 9-20, 2007.

SCHONE, R. A.; NUNES, R. V.; FRANK, R.; EYNG, C.; CASTILHA, L. D. Resíduo seco de destilaria com solúveis (DDGS) na alimentação de frangos de corte (2242 dias). Revista Ciência Agronômica, Fortaleza, v. 48, n. 3, p. 548-557, 2017. 
SILVA, M. T. P. Desempenho de três genótipos de frangos de corte alimentados com diferentes niveis nutricionais. 2013. Dissertação (Mestrado em Zootecnia) - Universidade Federal dos Vales do Jequitinhonha e Mucuri, Diamantina.

UNIVERSIDADE FEDERAL DE VIÇOSA - UFV. SAEG - Sistema para análise estatística e genética.
Viçosa, MG, 1999. CD-ROM.

WANG, X.; PEEBLES, E. D.; ZHAI, W. Effects of protein source and nutrient density in the diets of male broilers from 8 to 21 days of age on their subsequent growth, blood constituents, and carcass compositions. Poultry Science, Champaign, v. 93, n. 6, p. 1463-1474, 2014. 